\title{
A Multiplatform BIM-Integrated Construction Waste Quantification Model during Design Phase. The Case of the Structural System in a Spanish Building
}

\author{
Rocío Quiñones*(D), Carmen Llatas (D), Maria Victoria Montes (D) and Isidro Cortés (D) \\ Instituto Universitario de Arquitectura y Ciencias de la Construcción, Escuela Técnica Superior de Arquitectura, \\ Universidad de Sevilla, Av. de la Reina Mercedes, 2, 41012 Sevilla, Spain; cllatas@us.es (C.L.); \\ toya@us.es (M.V.M.); icortes@us.es (I.C.) \\ * Correspondence: mquinones@us.es; Tel.: +34-954-556626
}

check for updates

Citation: Quiñones, R.; Llatas, C.; Montes, M.V.; Cortés, I. A

Multiplatform BIM-Integrated

Construction Waste Quantification Model during Design Phase. The Case of the Structural System in a Spanish Building. Recycling 2021, 6, 62. https://doi.org/10.3390/ recycling 6030062

Academic Editor: Domenico Asprone

Received: 25 April 2021

Accepted: 9 September 2021

Published: 15 September 2021

Publisher's Note: MDPI stays neutral with regard to jurisdictional claims in published maps and institutional affiliations.

Copyright: (c) 2021 by the authors. Licensee MDPI, Basel, Switzerland. This article is an open access article distributed under the terms and conditions of the Creative Commons Attribution (CC BY) license (https:// creativecommons.org/licenses/by/ $4.0 /)$.
Abstract: Construction waste $(\mathrm{CW})$ is a prime contributor to the stream of total waste worldwide. One of the biggest challenges of the construction industry is to minimise $\mathrm{CW}$ and to develop practices of a more sustainable nature for its management and recycling in order to promote its transition towards a more effective circular economy. The implementation of these practices contributes towards mitigating the scarcity of natural resources and the environmental impact of CW. Thus, a preceding and essential step is the estimation of $\mathrm{CW}$ during building design, which will allow the adoption of measures for its early reduction and optimisation. For this purpose, Building Information Modelling (BIM) has become a useful methodology to predict waste during the early stages of design. There remains, however, a lack of instrumental development. Therefore, this study proposes a BIM-based method to estimate $\mathrm{CW}$ during building design by integrating a consolidated construction waste quantification model in three different BIM platforms. For its validation, the method is applied to the structural system of a Spanish residential building. The results provide evidence that the proposed method is vendor-neutral and enables the automatic identification and quantification of the waste generated by each building element during the design stage in multiple BIM platforms.

Keywords: BIM; construction waste estimation; building design platform; European List of Waste; attributes; Allplan; Archicad; Revit; BIM objects

\section{Introduction}

The construction industry constitutes a key sector in the sustainable development of the worldwide productive model system. In the European Union (EU) alone, the construction sector contributes approximately $9 \%$ of gross domestic product and provides 18 million direct jobs [1]. On the other hand, it produces approximately 35\% of all greenhouse gas emissions, accounts for $40 \%$ of total EU final energy consumption, and accounts for $25-30 \%$ of all waste generated [2].

With the rising cost of construction projects and growing environmental concerns, the construction industry is under immense pressure to become more resource efficient and to develop construction practices of a more sustainable nature. At international level, the United Nations' Sustainable Development Goals for 2030 demand sustainable cities and communities (goal 11), as well as responsible consumption and production (goal 12) [3]. In the EU, the Construction 2020 Strategy encourages the circular economy principles for the design of buildings [4-6] and calls for the reduction of waste and the facilitation of high-quality waste management.

Within the last decade, many research efforts have therefore been made to understand the causes of waste in construction projects, to assess its impact, and to propose eco-efficient strategies and best practices for its reduction, reuse, and recycling [7-13]. Furthermore, several 
studies have focused on the development of construction and demolition waste (CDW) quantification models [14-17] to support designers with data for appropriate decision-making at the design stage. Hence, waste reduction can be tackled through the comparative analysis of the amount of waste generated in different design alternatives [18,19]. The earlier that construction waste $(\mathrm{CW})$ is identified and measured in the life cycle of a building, the more successful are the minimisation measures adopted and the more efficient is the management deployed for the unavoidable stream of CW.

Nevertheless, it is argued that existing estimation tools and methods are insufficiently convenient for practitioners to be willing to utilise, since information such as material volume needs to be either measured or retrieved from available documents manually, which entails much time and effort. The appearance of new collaborative-based and rich information technologies in the Architecture, Engineering, and Construction (AEC) sector, such as Building Information Modelling (BIM), is considered as an opportunity to address construction waste problems from the design stage to obtain results of higher efficiency [20]. To this end, however, major development and standardisation of BIM-integrated tools for construction waste are required.

Therefore, this study aims to contribute towards filling this technological gap by designing and developing a BIM-based multiplatform methodology for the estimation of construction waste during building design, as a preceding and essential step for waste minimisation and sustainable management. This methodology integrates a Spanish model of CDW estimation [15] into the main three European BIM platforms (Allplan, Archicad, and Revit), and provides an automatic and detailed quantification of construction waste. This information will allow practitioners to implement construction waste minimisation and optimisation measures from the design stage through the whole life cycle of the building. Finally, a case study is provided to verify its functionality in the structural system of a dwelling located in Andalusia (Spain).

\section{BIM Methodology and Construction Waste}

The use of BIM in the AEC sector has increased in recent years. Since it first appeared in 1992 [21], the BIM concept has evolved from a simple 3D modelling methodology to a comprehensive project management tool and process [22]. Building Information Modelling enables better information sharing among construction project stakeholders throughout project life cycle, thereby contributing to an accurate decision-making and improved facility delivery process.

Owing to the heavy physical resource engagement in construction projects and to its one-off and irreversible nature, it is too expensive, if not impossible, to test different design and construction schemes before a project is built without employing new technologies. In this context, BIM is revealed as a powerful methodology and a versatile tool that helps to predict and understand possible improvements and changes to a building before they are adopted on site. Hence, BIM is regarded as a feasible methodology to address the performance problems of construction projects at an early stage before a large commitment of time or money has been made.

However, international studies reveal that construction waste research is not a priority issue among BIM research areas [23-25]. The core themes identified in the global research on BIM are mainly focused on general building environmental assessment and energy efficiency [26-29].

In the design stage, although still limited, several specific BIM-aided methods and tools have been developed to assess the amount of waste originated from construction, renovation, and demolition projects [30-32]. In particular, there is a general consensus on BIM's potential to improve the accuracy and quality of design, thereby reducing design errors, reworking, inefficiencies in communication and coordination between project participants, and unexpected design changes, which are all frequent causes of construction waste.

A number of these studies have focused on a specific type of waste. Porwal and Hewage [33] proposed a BIM-based method to analyse reinforced concrete structures to 
reduce reinforcement waste by selecting suitable lengths of rebars and considering available cut-off lengths. Guerra et al. [34] presented their BIM-based automated construction waste estimation algorithms for concrete and drywall waste streams.

Other authors envisioned the environmental potential of BIM at the end of the life cycle of the building and concentrated their efforts on the demolition stage. Cheng and Ma [35] designed a BIM application programming interface (API) for the estimation of demolition and renovation waste. Akinade et al. [36] provided the needed technological support for the development of tools for BIM-compliant Design for Deconstruction tools. Akanbi et al. [37] developed a BIM-based system for the estimation of the salvage value of building materials through the life cycle of a building. Furthermore, Zhang and Jia [38] propose a dynamic recycling BIM-based model for the disposal of construction materials across the whole life cycle.

As far as BIM software is concerned, most of the methods and tools have been developed for Autodesk Revit [31,35,39], and are not available for many practitioners that work with other software.

The more critical authors $[40,41]$ warn that BIM is not the panacea, since it cannot fix anything automatically. They consider that improvements in BIM computational implementation and interoperability are strongly needed to effectively address waste minimisation through BIM, by clarifying a way forward rather than simply adding mere rhetoric.

Likewise, according to recent studies, the actual implementation of BIM in the construction industry for construction waste assessment and management is also relatively low, and is focused on waste minimisation and on-site waste management [42,43]. However, stakeholders have major expectations for the use of BIM for construction and demolition waste management [44].

Since BIM potential has not yet been realised in the construction industry at the level of research and practitioners $[45,46]$, there is a clear need to speed up the development and standardisation of BIM-integrated tools for construction waste in order to provide a broader coverage of user requirements and information flows in the full life cycle of building projects; an opportunity to be addressed can thus be observed here.

\section{Materials and Methods}

\subsection{Selected Construction Waste Quantification Model}

The verified CDW quantification model $[15,16]$ estimates the amount of waste generated during the construction and demolition phases from the initial design stage. The types and quantities of CDW are estimated and managed according to EU guidelines, in terms of building elements, specifically for each project. The results are obtained in detail, for both building elements and building systems, and globally for the whole building. In addition, identified and quantified waste is classified according to the European Waste List (EWL) [47]. The model enables the detection of the source of the waste and other alternative solutions that reduce CDW. Likewise, it develops a systematic structure of the construction process, a waste classification system, and several analytical expressions, which are based on waste quantification factors. These factors depend on the construction technology available and represent an on-site standard.

At the same time, BIM methodology works in terms of its elements and its potential lies in the virtual simulation of building and construction processes before their implementation. The choice of this quantification model is justified, as it is also a model in terms of its building elements that are applicable in the design phase, which enables strategic decisions to be anticipated from early stages. Furthermore, the model uses waste quantification factors which have been obtained and validated for residential building typologies in Andalusia (Spain). Therefore, the model is considered suitable for application in this study. There are three methodological tools of the CDW quantification model [15] to be integrated into BIM methodology: 
- Input data: systematic classification of building construction process; identification and codification of building elements and construction systems in accordance with the Base de Costes de la Construcción de Andalucía (BCCA) 2017 [48].

- Quantification procedure: quantification of the number of building elements in accordance with the unit of measurement in the BCCA; quantification of waste based on analytical expressions and quantification factors developed in Llatas [15] and obtained for residential buildings in Andalusia in both Llatas [15] and Llatas and Osmani [16].

- Output data: amount of waste classified in accordance with the EWL [47] per building element, building system, and for the entire building.

\subsection{Selected BIM Design Software Products}

In contrast to other studies that use a single BIM software tool, this work proposes a triple methodological itinerary that explores the integration of the CDW quantification model into the most widely used BIM modelling platforms in Spain, certified by buildingSMART International [49]: Allplan 2021.0.2 [50], Archicad 24 [51], and Revit 2021.1.1 [52].

Building elements modelled in BIM can easily be described, either from element type and geometric dimensions (e.g., wall, window, and faucet), or they can be defined semantically by incorporating information through attributes (e.g., thermal transmittance, material quality, payload, and manufacturer). This capability of BIM elements in BIM design programs is employed to implement the CDW quantification model in BIM.

\subsection{Integration of $C D W$ Model in BIM}

Four steps are required to integrate the selected CDW estimation model into each BIM design software tool, as shown in Figure 1. First, the numerous building elements that make up the virtual model of the building are created. Second, the database that contains the CW model information is developed. Third, each building element is linked to the amount of waste that it produces. Finally, the results of the generated waste are obtained in terms of elements and then as the building as a whole, through the design of reports that filter the desired information.

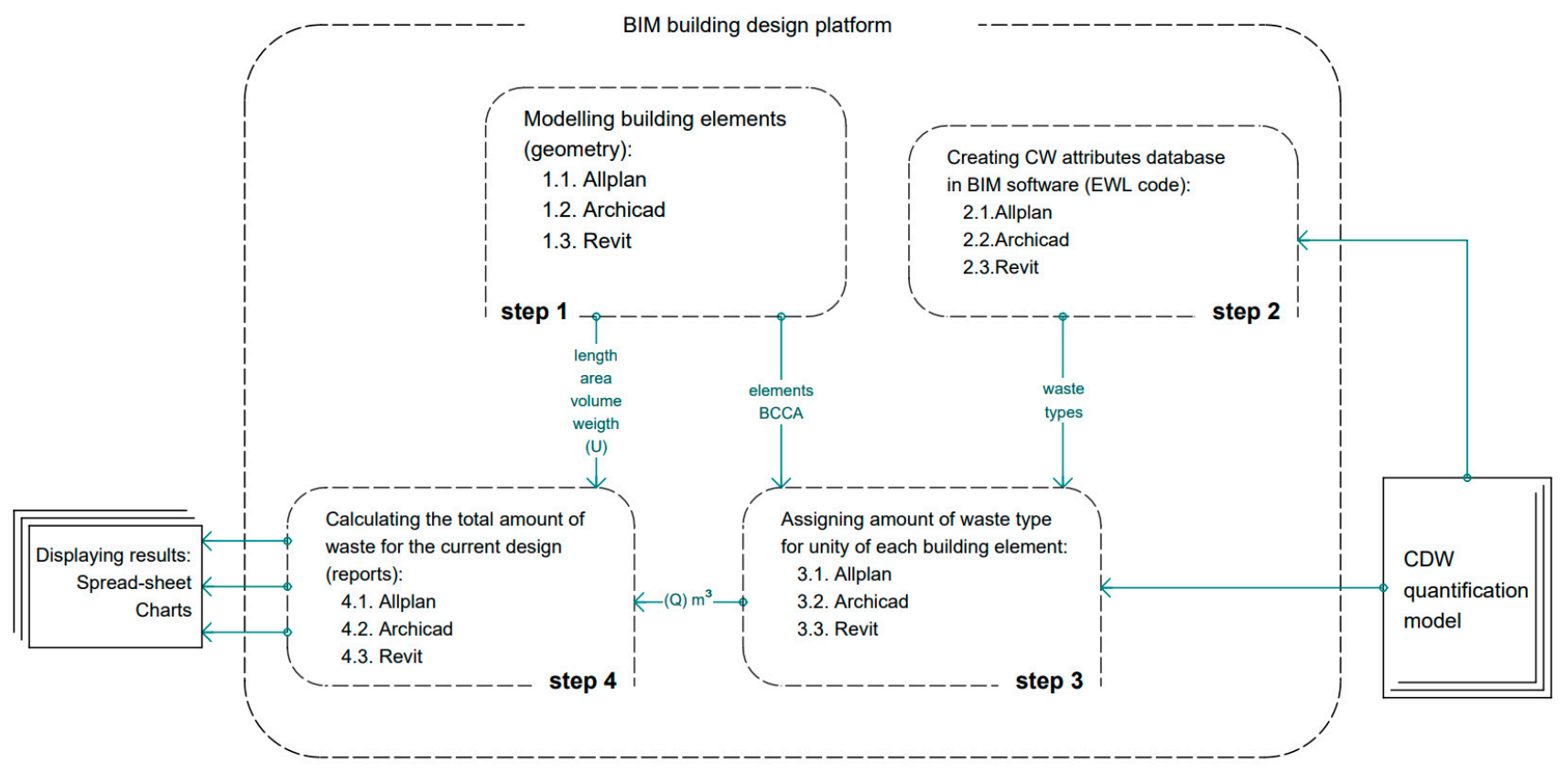

Figure 1. Flowchart of the developed methodology. 


\subsubsection{Step 1: Modelling Building Elements in BIM Design Software}

The process begins with the 3D geometric modelling of each element of the building system in each software tool. Each building element (e.g., foundation wall, slab, and column) is identified and modelled by defining its geometry, rendering properties, overall position in the project, and relative position to the other building elements. The level of development considered for elements is equivalent to the LOD 200 standard [53]: the approximate size and shape of elements, which provides sufficient information to obtain the volumes of the elements and to apply the quantification model. In order to unify the criteria of identification of the elements and their comparison with their equivalent elements in the other software tools, the use of the BCCA coding is proposed [48]. In addition, this classification is used in the selected CDW quantification model, thereby facilitating its integration. This classification is based on an alphanumeric code that identifies and locates each element in accordance with the building system to which it belongs.

\subsubsection{Step 2: Creating the Database of CW Attributese in BIM Design Software}

This phase involves the development of the databases with the types of $\mathrm{CW}$ that are intended to be quantified and evaluated in each BIM design program. These data do not exist by default in BIM modellers. The new attributes (additional information regarding CW linked to building elements) are named in accordance with the EWL encoding [47] (e.g., 170101 concrete). The usefulness of this encoding is that it helps to identify each type of waste. Table 1 shows an example of how the new $\mathrm{CW}$ attributes (the types of waste according to the EWL code) and properties are set in each BIM software tool.

Table 1. Example of new CW attributes to enrich building elements in the BIM model adapted to the case study.

\begin{tabular}{clccc}
\hline Type of Waste Coded & \multicolumn{3}{c}{ CW Attributes Database: Type of Parameter } \\
\hline According to the EWL & Unit & Allplan & Archicad & Revit \\
\hline 070701 aqueous washing liquids & $\mathrm{m}^{3}$ & Real & Volume & Volume \\
150102 plastic packaging & $\mathrm{m}^{3}$ & Real & Volume & Volume \\
150103 wooden packaging & $\mathrm{m}^{3}$ & Real & Volume & Volume \\
150104 metallic packaging & $\mathrm{m}^{3}$ & Real & Volume & Volume \\
150106 mixed packaging & $\mathrm{m}^{3}$ & Real & Volume & Volume \\
170101 concrete & $\mathrm{m}^{3}$ & Real & Volume & Volume \\
170201 wood & $\mathrm{m}^{3}$ & Real & Volume & Volume \\
170203 plastic & $\mathrm{m}^{3}$ & Real & Volume & Volume \\
170405 iron and steel & $\mathrm{m}^{3}$ & Real & Volume & Volume \\
170904 mixed & $\mathrm{m}^{3}$ & Real & Volume & Volume \\
\hline
\end{tabular}

a European Waste List (EWL) [47].

\section{Creating CW Attributes in Allplan}

The "Assign attribute" tool can be used to create the new CW attributes in the Allplan 2021.0.5 version. A new group of attributes, called Pset_ConstructionDemolitionWaste, is proposed since the native database contains no environmental group. The new attributes must represent numeric values related to the volume in Allplan by offering four options: text, real, whole number, and date; therefore, only the real number option is possible and the unit of measure is expressed in " $\mathrm{m}^{3}$ " with a maximum of six decimal places, as shown in Figure 2.

\section{Creating CW Attributes in Archicad}

In Archicad 24, the "PropertyManager" tool is used (see Figure 2). The new CW attributes are created in the already existent "ENVIRONMENT" group. The program offers many options for the value of the attributes: chain, number, whole number, length, area, volume, angle, true/false, screen list, and set of options. In this case, "volume" is selected 


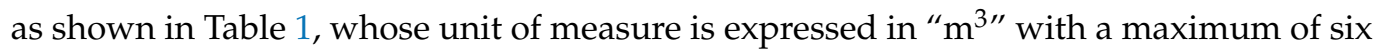
decimal places.

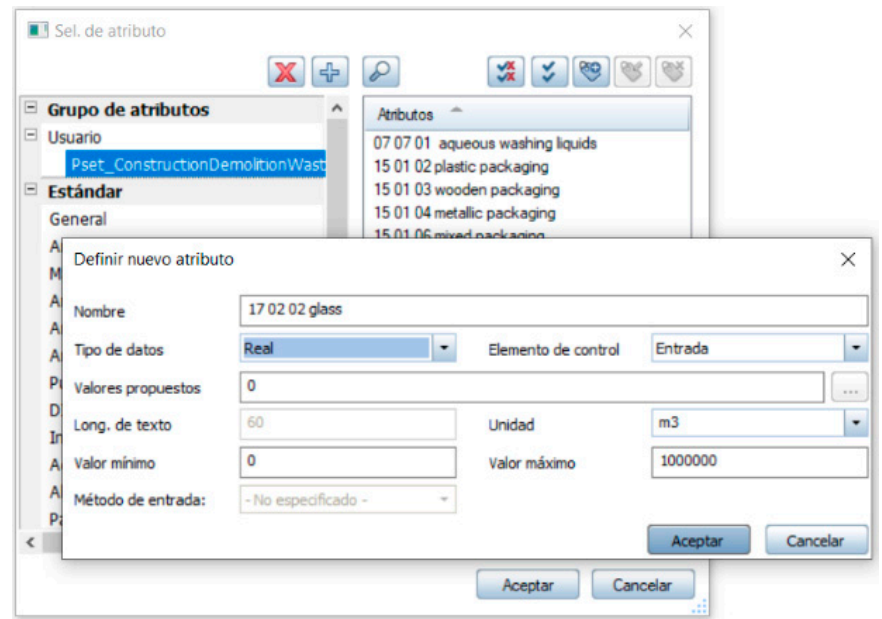

(a)

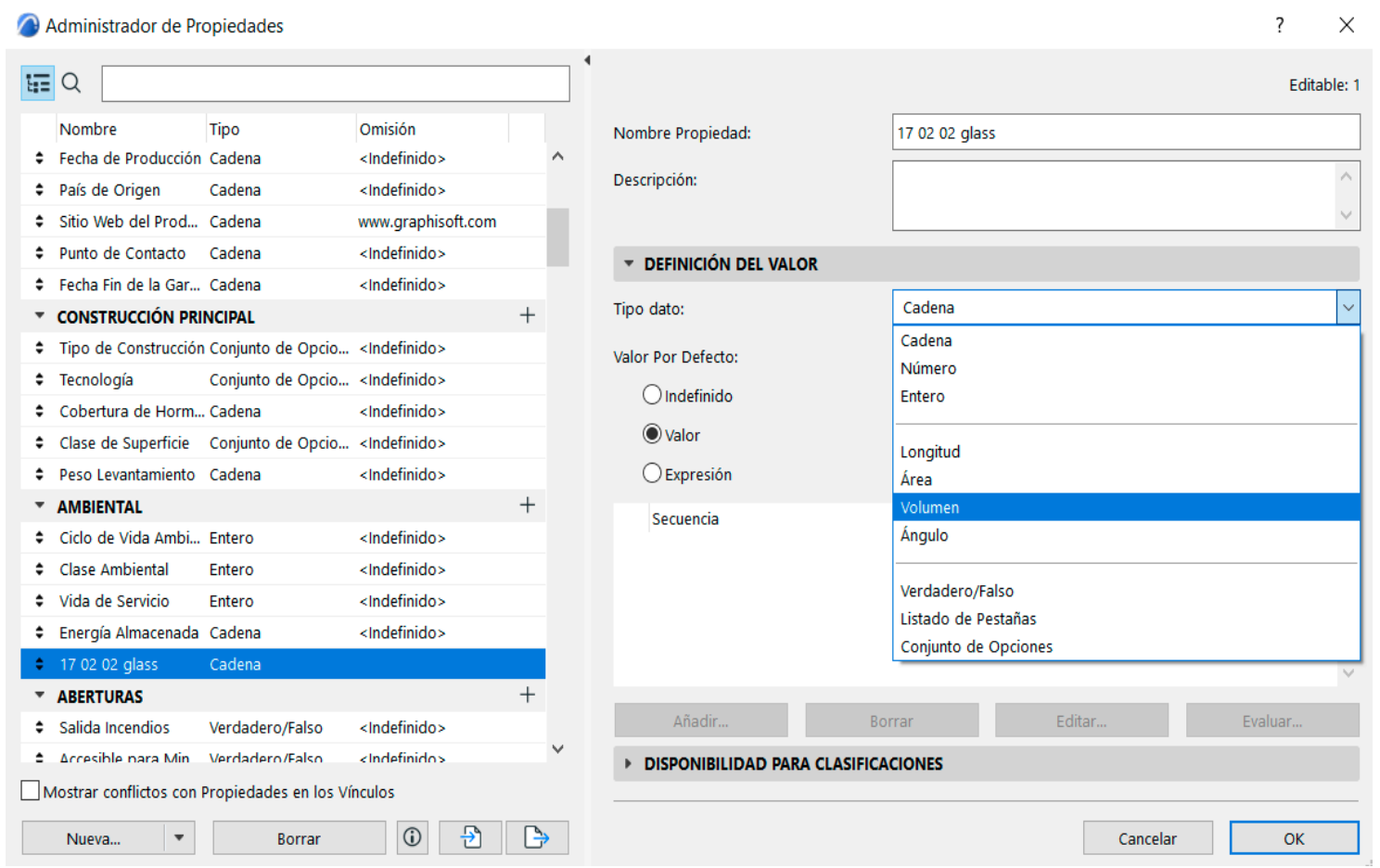

(b)

Figure 2. Panel for the definition of attributes and type of parameters: (a) Allplan; (b) Archicad.

Creating CW Attributes in Revit

In the Revit 2021.1.1 version, the tools used are "Shared parameters" and "Project Parameters" (see Figure 3). These tools are necessary if the parameters of a family are required to be reportable in tables in a project. A new CW attribute in the existing "Green Building" group is developed, although Revit has numerous options for expressing values, including volume (e.g., text, whole number, angle, area, distance, length, rotation angle, pending, speed, time, currency, URL, and material). The parameter value selected is "volume" (see Table 1) to express CW attributes and the unit chosen to express the values is $\mathrm{m}^{3}$, as shown in Figure 3. 


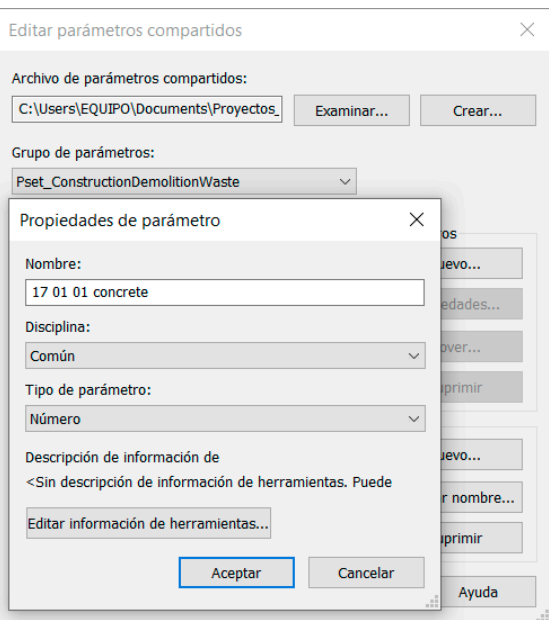

(a)

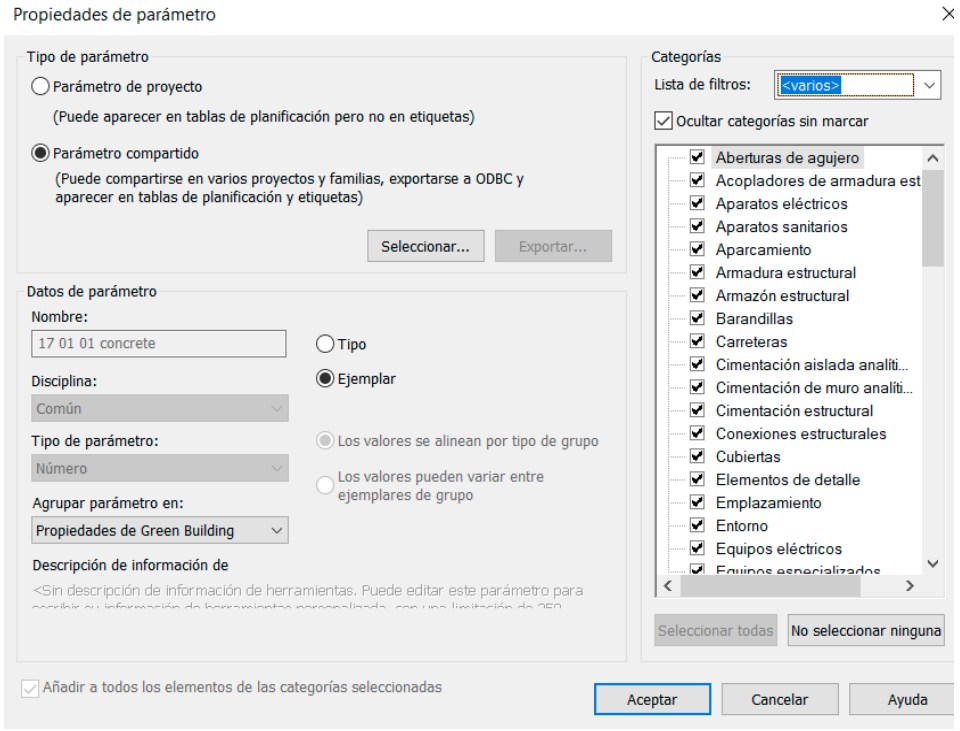

(b)

Figure 3. Panel for the definition of attributes and type of parameters in Revit: (a) Editing shared parameter panel; (b) Parameter property panel.

\subsubsection{Step 3: Assigning Amount of Waste Type per Unit of Each Building Element}

Once each building element is identified, modelled, and encoded in the first step, and the CW database is created in the second step, it is necessary to link the CW values to each entity considering the waste quantification factors of the CDW model [15].

The assignment of the values is carried out through the "Properties Panel" of each building element in the three BIM programs, that is, within each entity the information of the CW types is added according to the EWL [47] and the amount of CW generated per unit of building element is quantified according to the analytical expressions of the CDW quantification model [15]. Figure 4 shows an example of the attributes assigned to a building slab in the Allplan software.

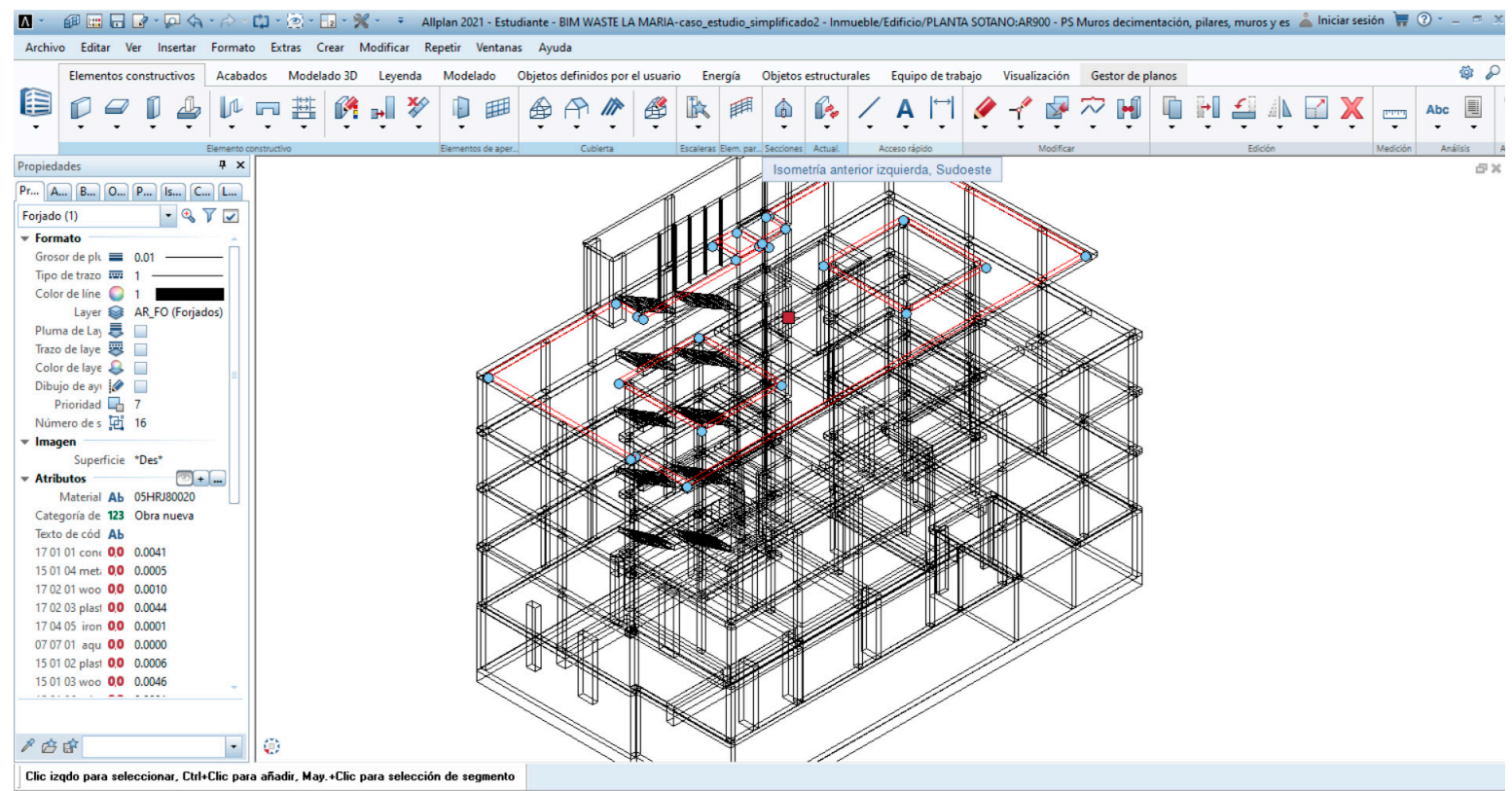

Figure 4. Example of the slab properties panel in Allplan: waste types with assigned values per unit of measure. 
Table 2 shows the values calculated for the foundations and elements of the structural system from the study of residential buildings in Andalusia. This table offers only one representative example. The table indicates the unit of measure of each building element, and the amount of each element constructed; in this case a unit value of " 1 " is used. The analytical expressions of the CDW quantification model employed to calculate both the packaging and remains (losses, breakages, etc.) are summarised below. In order to obtain the total amount of CW per building element, the " $Q$ " quantity of the building element should be multiplied.

The types and quantities of packaging waste generated by each building element, coded on the EWL, are estimated by Equation (1):

$$
\mathrm{CW}_{\mathrm{Pi}}=\sum_{k}(\mathrm{EWL})_{\mathrm{Pk}} \cdot Q_{i} \cdot F_{P} \cdot F_{C} \cdot F_{I}
$$

where $\mathrm{CW}_{\mathrm{Pi}}$ is the volume of the packaging waste expected for the building element number " $i$ "; $(E W L)_{P k}$ is the code of the packaging waste number " $k$ " according to the EWL; $Q_{i}$ is the amount of building element number " $i$ " in the unit of measurement of the project $(\mathrm{U}) ; F_{P}$ is the packaging waste factor; $F_{C}$ is the conversion factor; and $F_{I}$ is the increased volume factor.

The types and quantities of remains generated by each building element, coded on the EWL, are estimated by Equation (2):

$$
\mathrm{CW}_{\mathrm{Ri}}=\sum_{k}(\mathrm{EWL})_{\mathrm{Rk}} \cdot Q_{i} \cdot F_{R} \cdot F_{C} \cdot F_{I}
$$

where $\mathrm{CW}_{\mathrm{Ri}}$ is the volume of the remains expected in the building element number " $i$ "; $(\mathrm{EWL})_{\mathrm{Rk}}$ is the code of the remains number " $k$ " according to the EWL; $Q_{i}$ is the amount of building element number " $i$ " in the unit of measurement of the project $(U) ; F_{R}$ is the remains factor; $F_{C}$ is the conversion factor; and $F_{I}$ is the increased volume factor.

The quantification factors of each building element have been taken from the estimation CDW model $[15,16]$.

\subsubsection{Step 4: Quantification, Visualisation, and CW Assessment}

Finally, the total amount of CW per building element is calculated by multiplying the quantity of the building element (Q), according to the BCCA measurement criteria, by each value of the waste type volume assigned (Table 2 ).

The geometrical information of the elements, together with the information of the CW attributes and values assigned to these elements, can be extracted and presented through reports in which the mathematical operations are performed. The data can be located and grouped according to predefined criteria, and can be filtered with conditions, for example by selecting only the slabs, or by excluding elements with zero value. For the quantification of CW and its evaluation, two standard reports can be designed: the first identifies the quantity of each type of waste generated per building element, while the second collects a summary of the total quantity per type of waste.

The tools selected for the design of result reports may include "Legend" in Allplan, "Outline Definitions" in Archicad, and "Planning Tables" in Revit. Figure 5 shows a standard report designed in Allplan 2021 where the parameters and formulae are defined through cells distributed in rows and columns.

Although it is not possible to obtain automatic charts from this BIM software, a further study enables this type of data to be obtained from the reports through other tools, such as Excel. 
Table 2. CW expected in building elements. Data based on Llatas, 2011 [15] and Llatas and Osmani, 2016 [16].

\begin{tabular}{|c|c|c|c|c|c|c|c|c|c|c|c|c|c|}
\hline & & & \multicolumn{11}{|c|}{ Volume $\left(\mathrm{m}^{3}\right)$ of Packaging Waste, Remains and Soil by Building Element } \\
\hline & & & \multicolumn{4}{|c|}{ Packaging Waste } & \multicolumn{2}{|c|}{ Remains Waste } & \multirow{2}{*}{\multicolumn{2}{|c|}{1702}} & \multirow[b]{2}{*}{1704} & \multirow[b]{2}{*}{1709} & \multirow{2}{*}{$\begin{array}{c}\text { Soil } \\
1705\end{array}$} \\
\hline \multirow{2}{*}{\multicolumn{3}{|c|}{ Type of Waste $\left(\mathrm{m}^{3}\right)$ According to the EWL ${ }^{b}$}} & \multicolumn{4}{|c|}{1501} & \multirow{2}{*}{$\begin{array}{c}07 \\
\text { organic } \\
\text { chemical } \\
\text { processes }\end{array}$} & \multirow{2}{*}{$\begin{array}{c}1701 \\
\text { concrete, } \\
\text { bricks, tiles } \\
\text { and ceramics }\end{array}$} & & & & & \\
\hline & & & & Packag & waste & & & & \multicolumn{2}{|c|}{ wood, glass and plastic } & \multirow{2}{*}{$\begin{array}{c}\text { metals } \\
\\
170405 \\
\text { iron }\end{array}$} & mixed & \multirow{2}{*}{$\begin{array}{c}\text { soil } \\
170504 \\
\text { soil and } \\
\text { stones }\end{array}$} \\
\hline U & $\begin{array}{l}\text { BCCA }^{a} \\
\text { code }\end{array}$ & $\begin{array}{c}\text { Building/Sitework } \\
\text { element }\end{array}$ & $\begin{array}{c}150102 \\
\text { plastic } \\
\text { packaging }\end{array}$ & $\begin{array}{c}150103 \\
\text { wooden } \\
\text { packaging }\end{array}$ & $\begin{array}{c}150104 \\
\text { metalic } \\
\text { packaging }\end{array}$ & $\begin{array}{c}150106 \\
\text { mixed } \\
\text { packaging }\end{array}$ & $\begin{array}{c}070701 \\
\text { aqueous } \\
\text { washing } \\
\text { liquids }\end{array}$ & $\begin{array}{l}170101 \\
\text { concrete }\end{array}$ & $\begin{array}{l}170201 \\
\text { wood }\end{array}$ & $\begin{array}{l}170203 \\
\text { plastic }\end{array}$ & & $\begin{array}{c}170904 \\
\text { mixed }\end{array}$ & \\
\hline $\mathrm{m}^{3}$ & 02AVV00003 & Site clearing & & & & & & & & & & & 1.100000 \\
\hline $\mathrm{m}^{3}$ & 03HRL80090 & Concrete ground slab & & & & & & 0.022000 & & & 0.000050 & 0.000221 & \\
\hline $\mathrm{m}^{3}$ & 03HRM80080 & Foundation wall & & & 0.001018 & 0.000010 & 0.000017 & 0.022000 & 0.003944 & & 0.000193 & 0.000262 & \\
\hline $\mathrm{m}^{3}$ & 05HRL80020 & Concrete deck & & & 0.002867 & 0.000029 & 0.000049 & 0.022000 & 0.008330 & & 0.000378 & 0.000308 & \\
\hline $\mathrm{m}^{3}$ & 05HRJ80110 & Dropped beam & & & 0.003045 & 0.000030 & 0.000041 & 0.022000 & 0.008893 & & 0.000078 & 0.000310 & \\
\hline $\mathrm{m}^{2}$ & 05WCH80110N & Waffle slab $(25+5 \mathrm{~cm})$ & 0.000554 & 0.004619 & 0.000468 & 0.000056 & 0.000008 & 0.004070 & 0.001020 & 0.004385 & 0.000055 & 0.000095 & \\
\hline $\mathrm{m}^{2}$ & 05WCH80110 & Waffle slab $(30+5 \mathrm{~cm})$ & 0.000609 & 0.005081 & 0.000515 & 0.000062 & 0.000009 & 0.004477 & 0.001122 & 0.004823 & 0.000061 & 0.000105 & \\
\hline $\mathrm{m}^{3}$ & 05HRJ80020 & Beam embbeded floor & & & 0.002907 & 0.000029 & 0.000039 & 0.022000 & 0.008488 & & 0.000078 & 0.000306 & \\
\hline $\mathrm{m}^{3}$ & 05HRP80020 & Concrete column & & & 0.019147 & 0.000191 & 0.000344 & 0.022000 & & & 0.000990 & 0.000233 & \\
\hline $\mathrm{m}^{3}$ & 05HRL80080 & Inclined slab & & & 0.000001 & 0.000000 & 0.000066 & 0.022000 & 0.011390 & & 0.000403 & 0.000339 & \\
\hline $\mathrm{m}^{3}$ & 05HRM80050 & Concrete wall & & & 0.019147 & 0.000191 & 0.000344 & 0.022000 & & & 0.000146 & 0.000225 & \\
\hline
\end{tabular}

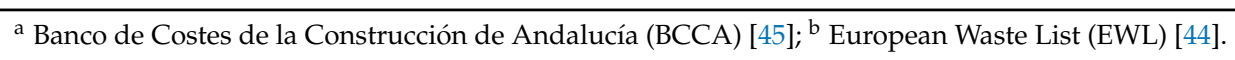




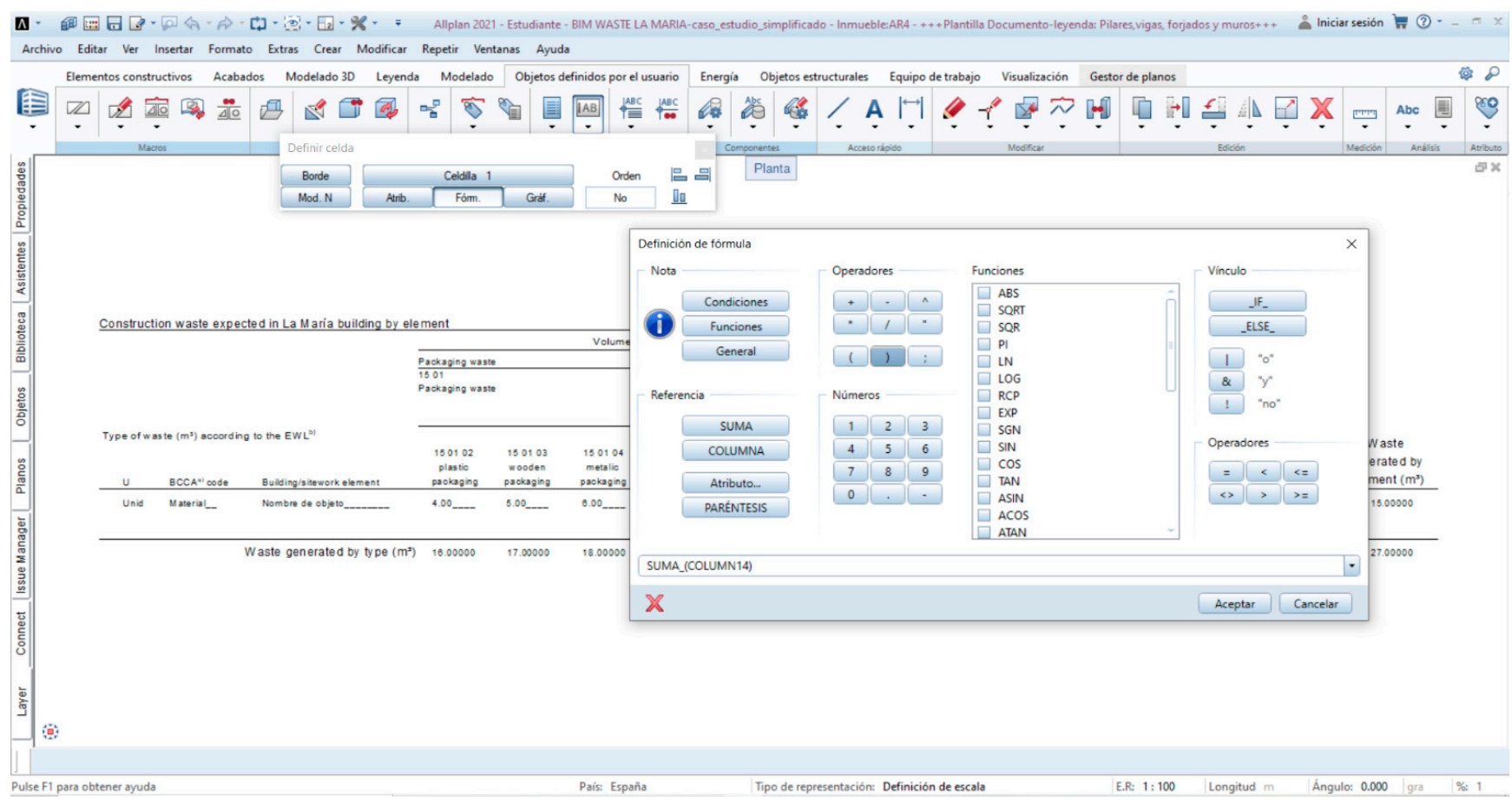

Figure 5. Report design tool in Allplan 2021.

\subsection{Case Study}

A case study is provided to explore the feasibility of the method in each software tool. A residential building with sixteen dwellings, located in Seville, Spain, was selected. The building was promoted by EMVISESA [54], a public enterprise dedicated to the construction of public housing. The GFA (gross floor area) is $2.314 \mathrm{~m}^{2}$, distributed across four floors above ground level and one floor below ground level. The structural system is made up of reinforced concrete frames and the foundations are composed of reinforced concrete slab. The method is applied to the structural system, including the foundation system. Figure 6 shows an example of the model in each of the three BIM modelling programs: Allplan, Archicad, and Revit.

This building typology is representative according to the statistical data of the Spanish Ministry of Development [55]. As Table 3 shows, new construction predominates over rehabilitation work, as does the typology of residential buildings over that of non-residential buildings, both in Andalusia and across Spain.

On the other hand, in accordance with the building system configuration, Table 4 relates the properties of new residential buildings, where the reinforced concrete structural system predominates. The data was collected from the building licences granted by Spanish and Andalusian town halls for buildings built between 2013 and 2017.

Table 3. Number of buildings according to construction type. Spanish Ministry of Development (2017).

\begin{tabular}{ccc}
\hline & Spain & Andalusia \\
\hline New building for residential use & 24.946 & 5.667 \\
New building for non-residential use & 8.149 & 2.215 \\
Rehabilitation work & 28.581 & 5.135 \\
Demolition work & 6.989 & 1.378 \\
\hline
\end{tabular}




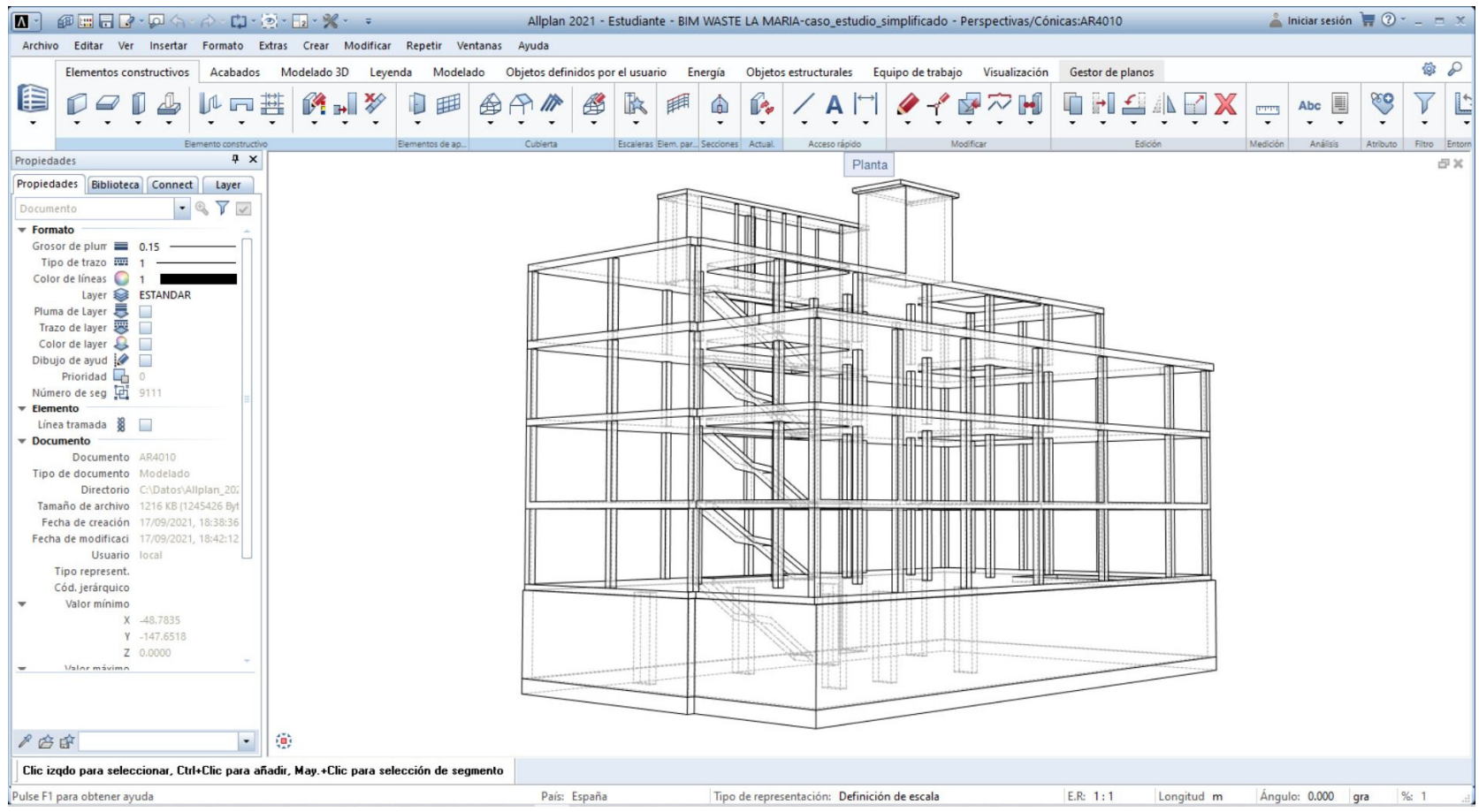

(a)

(2) La_Maria_varchicad24 - ARCHICAD 24 EDU

Archivo Edición Ver Diseño Documento Opciones Teamwork Ventanas Ayuda

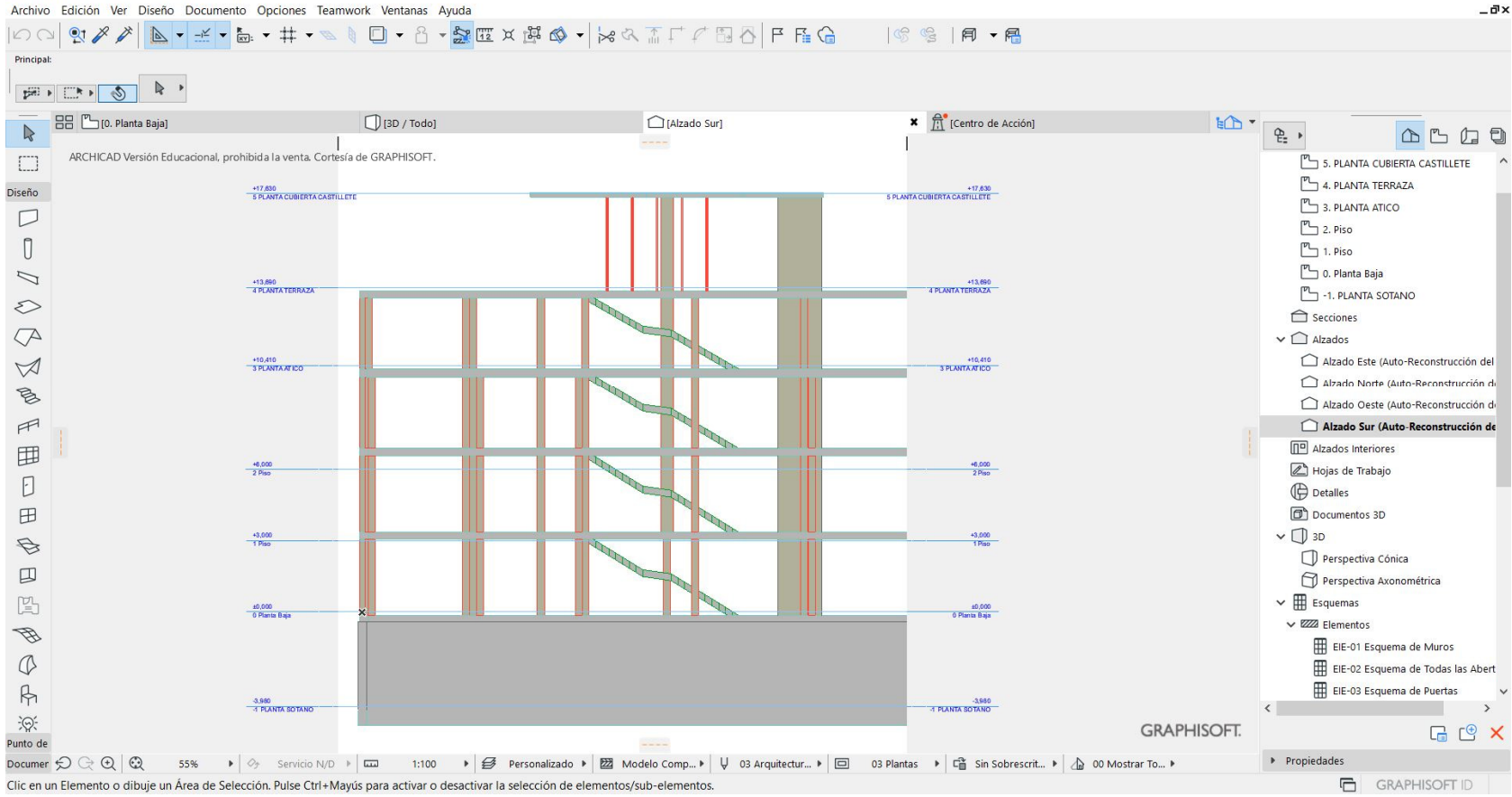

(b)

Figure 6. Cont. 


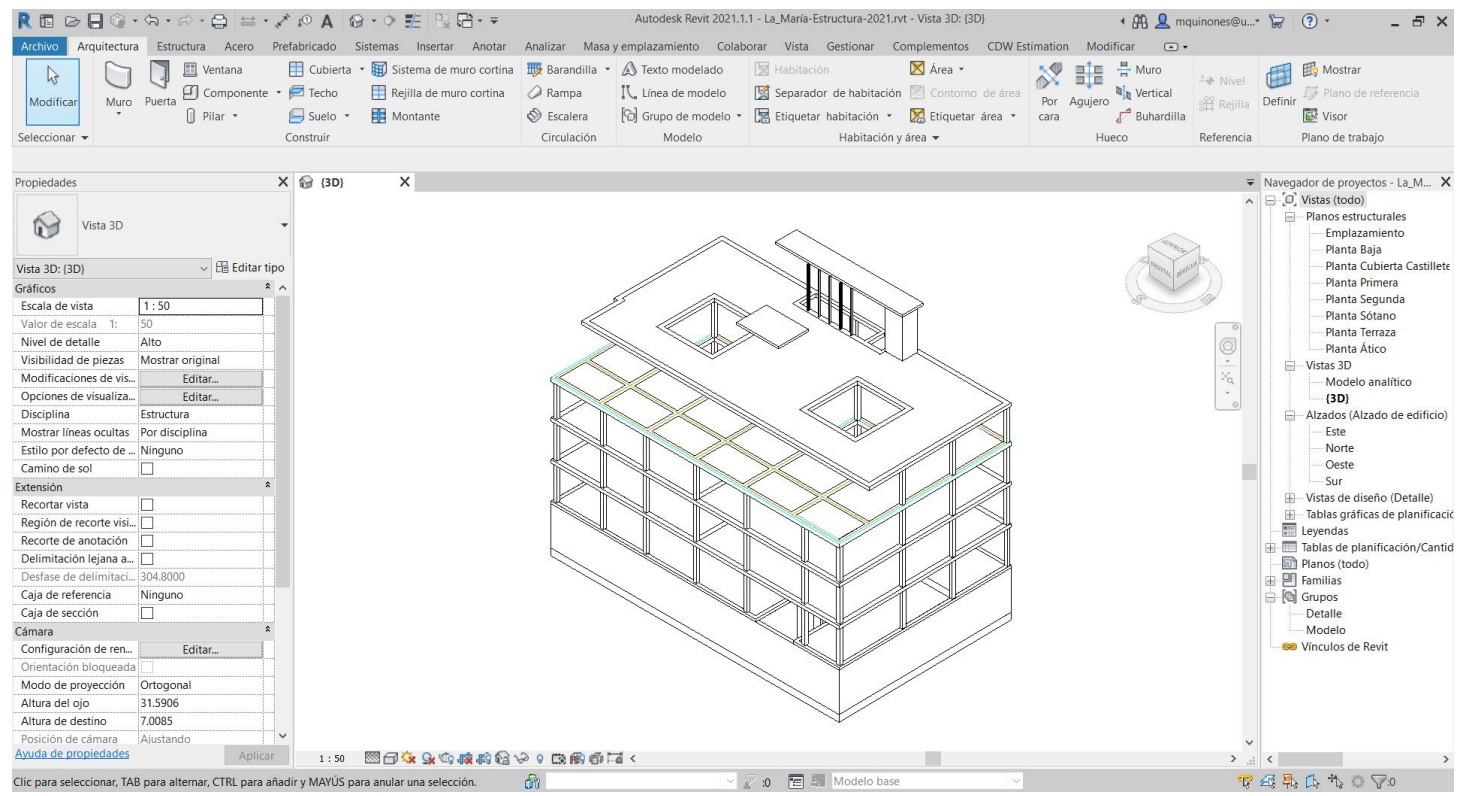

(c)

Figure 6. Structure system modelled in BIM: (a) Allplan; (b) Archicad; (c) Revit.

Table 4. Features of new residential buildings in Spain (2017).

\begin{tabular}{ccc}
\hline & \multicolumn{2}{c}{ Number of Buildings } \\
\cline { 2 - 3 } & Spain & Andalusia \\
\hline Vertical building structure & & \\
\hline Reinforced concrete & 17.931 & 4.829 \\
Metallics & 2.361 & 401 \\
Load-bearing walls & 3.103 & 288 \\
Mixes and others & 1.551 & 149 \\
\hline Horizontal building structure & & \\
\hline One-way slab & 17.732 & 3.194 \\
Other & 7.214 & 2.473 \\
\hline
\end{tabular}

\section{Results}

The building elements were identified, both in the foundation system (concrete slab, foundation walls) and in the structure system (concrete columns, slabs, and waffle slabs), as shown in Table 5. Subsequently, they were modelled in each BIM software tool and coded in a unified manner in accordance with the BCCA [48].

Once modelled, they were enriched with the CW attributes in the three BIM software tools analysed in accordance with Section 3.3.2. Step 2 (Table 1). The CW was subsequently calculated by multiplying the quantities of materials obtained by their corresponding parameters. This procedure was carried out by exporting the quantities of elements extracted from BIM into Excel calculation tables in each software tool. All the software tools identified the same types of waste and obtained similar amounts. Table 5 displays the CW quantities produced by each building element, by the building system, and by the type of waste listed according to the EWL code.

The BIM design programs provide tools to filter the results according to various criteria. An example of the results of the waste produced by the concrete slabs is shown in Figure 7.

Finally, the reports can be exported to spreadsheets and charts are obtained as shown in Figure 8, where Excel software was used. 
Table 5. Construction waste expected by building elements, obtained in Allplan, Archicad, and Revit.

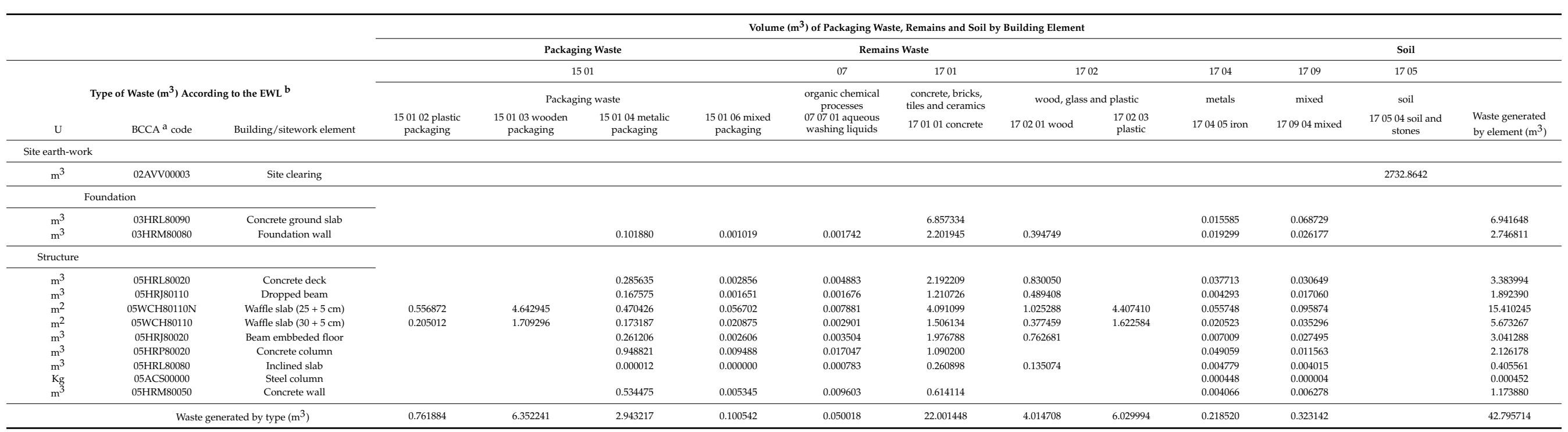

a Banco de Costes de la Construcción de Andalucía (BCCA) [45]; ${ }^{\mathrm{b}}$ European Waste List (EWL) [44] 


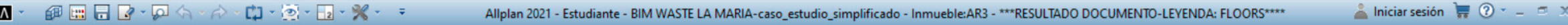
Archivo Editar Ver Insertar Formato Extras Crear Modificar Repetir Ventanas Ayuda

Elementos constructivos Acabados Modelado 30 Leyenda Modelado Objetos definidos por el usuario Energía Objetos estructurales Equipo de trabajo Visualización Gestor de planos

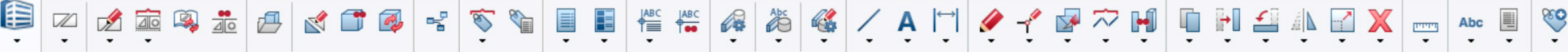

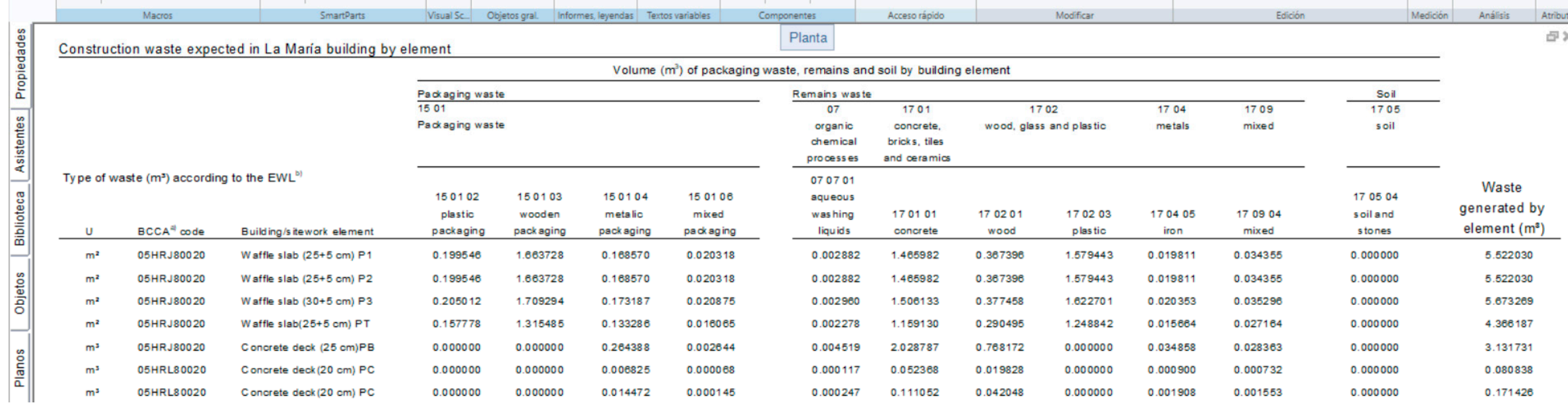

(a)

(2) La_María - ARCHICAD 24 EDU

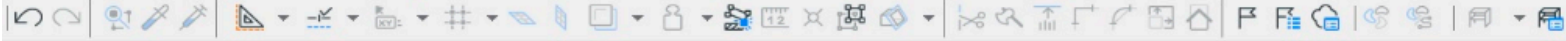

Principat

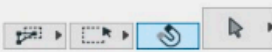

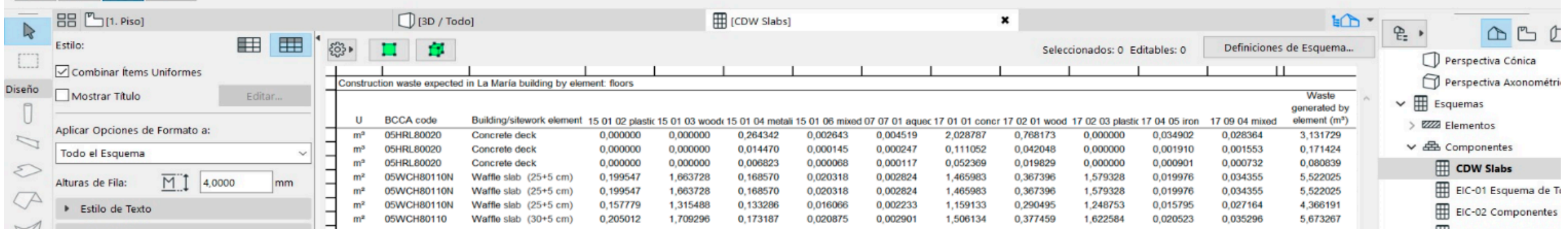

(b)

Figure 7. Cont 


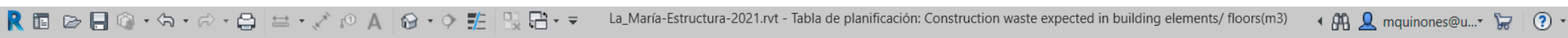

Archivo Arquitectura Estructura Acero Prefabricado Sistemas Insertar Anotar Analizar Masay emplazamiento Colaborar Vista Gestionar Complementos Modificar Modificar tabla de planificación/cantidades @.

Propiedades Nombre de...

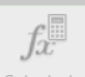

$f_{x}$

草

Sil Ocultar Insertar -

$\doteqdot$ Cambiar tamaño 团 Fusionar Separar

Oy Sombreado $\mathrm{A}_{\text {g Tipo de letra }}$

Propiedades Parámetros

Modificar tabla de planificación/cantidades

Propiedades

Tabla de planificación

Tabla de planificación: Constructior $\vee$ 㫬 Editar tipo

Datos de identidad

Plantilla de vista $\quad$ <Ninguno>

Nombre de vista

Proceso por fases Construction was Independiente Mostrar todo ⿶î. Mostrar todo $\square$ insertar fila de dato

F" Suprimir

国 Insertar imagen 医 Desagrup

$\boxplus$ Bordes

Alinear horizontalmente

譬 Alinear verticalmente - Resalta Column

$$
\text { Títulos y encabezamientos }
$$$$
\text { Aspecto }
$$

remento

\section{$x$ Construction waste expected in... $x$}

<Construction waste expected in building elements/ floors $(\mathrm{m} 3)>$

\begin{tabular}{|c|c|c|c|c|c|c|c|c|c|c|c|c|c|}
\hline A & $\mathrm{B}$ & $\mathrm{C}$ & D & $E$ & $F$ & $G$ & $\mathrm{H}$ & 1 & $J$ & $\kappa$ & $L$ & M & $N$ \\
\hline 4 & $B C C A$ & Tipo & 102 plasti & $0103 \mathrm{v}$ & 0104 meta & 0106 mix & 0101 con & 70701 aque & $70201 \mathrm{w}$ & 0203 plasti & 0405 iron & $70904 \mathrm{~mm}$ & Waste \\
\hline $\mathrm{m} 3$ & 05HRL80020 & Concrete deck $200 \mathrm{~mm}$ & 0 & 0 & 0.014473 & 0.000146 & 1.11056 & 0.000247 & 0.04205 & 0 & 0.001908 & 0.001555 & \begin{tabular}{|l|l}
1.170939 \\
\end{tabular} \\
\hline m3 & 05HRL80020 & Concrete deck $200 \mathrm{~mm}$ & 0 & 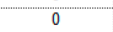 & 0.006823 & 0.000069 & 0.5236 & 0.000117 & 0.019825 & 0 & 0.0009 & 0.000733 & 0.552067 \\
\hline $\mathrm{m} 3$ & 05HRL80020 & Concrete deck $250 \mathrm{~mm}$ & 0 & 0 & 0.264432 & 0.002675 & 2.029126 & 0.004519 & 0.768301 & 0 & 0.034864 & 0.028408 & 3.132325 \\
\hline & 05 WWCH80110N & Waffle slab $250+50 \mathrm{~mm}$ & 0.199591 & 1.664096 & 0.168607 & 0.020175 & 1.466307 & 0.002882 & 0.367477 & 1.579793 & 0.019815 & 0.034226 & 5.52297 \\
\hline $\mathrm{m} 2$ & 05WCH80110N & Waffle slab $250+50 \mathrm{~mm}$ & 0.199591 & 1.664096 & 0.168607 & 0.020175 & 1.466307 & 0.002882 & 0.367477 & 1.579793 & 0.019815 & 0.034226 & 5.52297 \\
\hline $\mathrm{m} 2$ & 05WCH80110N & Waffle slab $250+50 \mathrm{~mm}$ & 0.156635 & 1.305948 & 0.13232 & 0.015833 & 1.150727 & 0.002262 & 0.288389 & 1.239789 & 0.01555 & 0.02686 & 4.334312 \\
\hline $\mathrm{m} 2$ & 05WCH80110 & Waffle slab $300+50 \mathrm{~mm}$ & 0.206139 & 1.719858 & 0.174321 & 0.020986 & 1.515411 & 0.003046 & 0.379784 & 1.632866 & 0.020648 & 0.035541 & 5.7086 \\
\hline
\end{tabular}

(c)
- Navegador de proyectos $-L . . . X$ 'Da' Vistas (todo) 由. Planos estructurale Vistas 3D Mod T- Alzados (Alzado de edifii
Tistas de diseño (Detalle \#-Tablas gráficas de planifi Leyendas

Tablas de planificación/ce Construction waste exp Tabla de planificación de

Figure 7. Examples of reports of the waste produced by the concrete slab in: (a) Allplan; (b) Archicad; (c) Revit. 


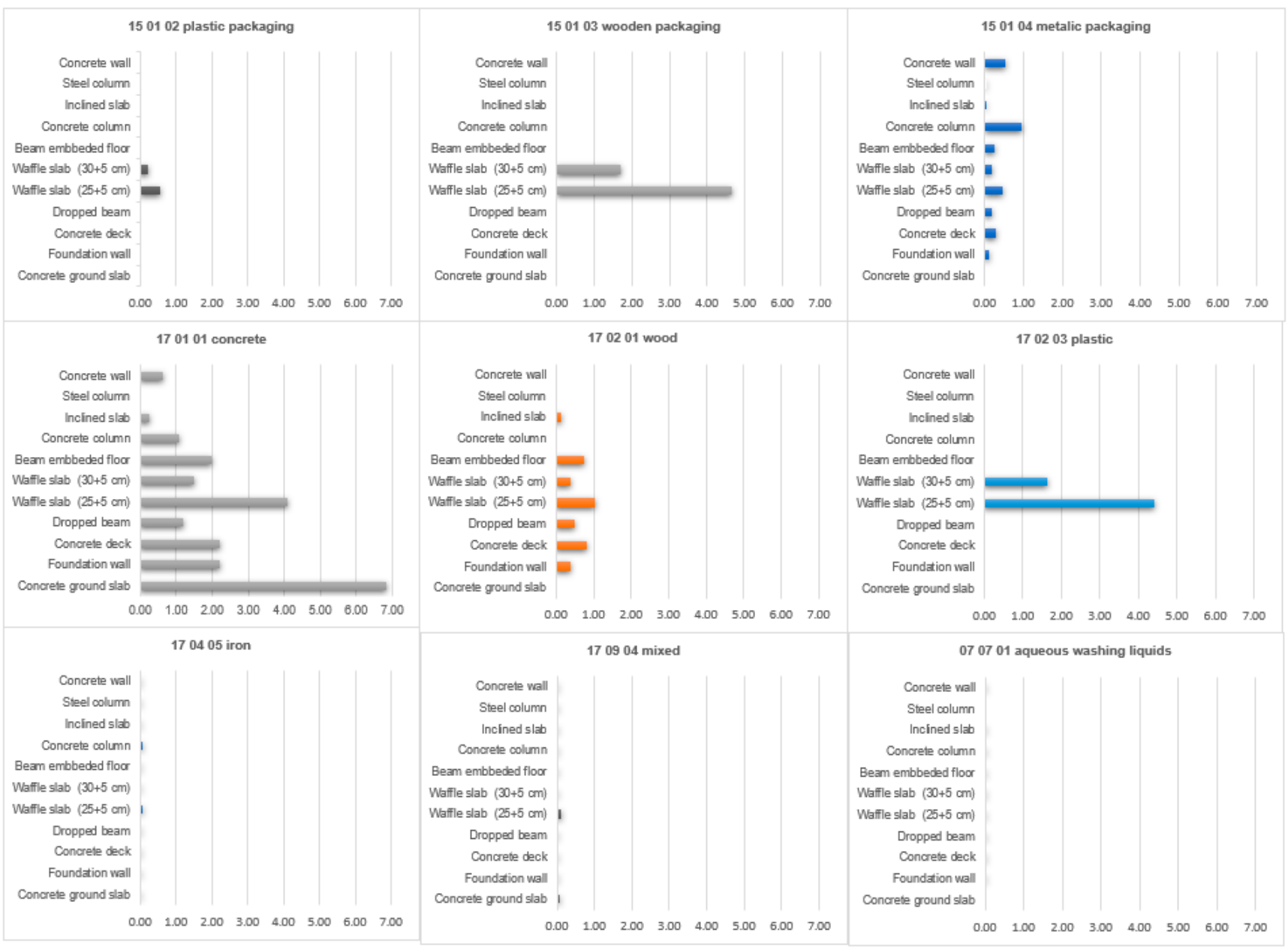

Figure 8. Chart with results produced in Excel obtained from reports in Allplan, Archicad, and Revit.

\section{Analysis and Discussion of Results}

\subsection{Integration of the CDW Model in BIM}

It has been possible to integrate the CDW quantification model $[15,16]$ into each of the three BIM design programs.

- The limitation of six decimal places to express volume quantities in Allplan and Archicad has meant that their figures have been rounded up more than in Revit, although the final results have not been altered.

- Another issue considered in the quantification in all the software tools was that the magnitudes necessary to define $Q$ that differ in length, area, or volume cannot be obtained directly, and therefore intermediate steps are required (e.g., $\mathrm{kg}$ of steel (05ACS00000), Q (kg)=7.850 kg/m $\times$ Volume $\left(\mathrm{m}^{3}\right)$ ).

- In all cases (Allplan, Archicad, and Revit), the assignment of the CW values of each building element must be entered manually (Step 3). Moreover, the most timeconsuming phase is that of the development of the database. However, once these CW databases linked to each BIM object have been prepared, the calculations are carried out automatically. Finally, future developments should explore greater automation of the data entered, both in the visualisation of the results, and in the interoperability between software tools.

- The design of result tables in each of the programs presents a variety of difficulties. Allplan is the most complex application because, unlike Archicad or Revit, the func- 
tions for defining and operating in the result tables are less intuitive. On the other hand, Allplan is more versatile in design options.

Therefore, the model is feasible for its integration into all three of the software tools.

\subsection{Estimation of the $C W$}

The types and quantities of CW could be estimated in Allplan, Archicad, and Revit in an automated way. The three software tools identified the same types of $\mathrm{CW}$ and obtained the same amount of CW. A total CW generation of $1.1995 \mathrm{~m}^{3} / \mathrm{m}^{2}$ was estimated. Three main groups of $C W$ were identified with the following generation ratios: $0.0043 \mathrm{~m}^{3} / \mathrm{m}^{2}$ of packaging waste, $0.0141 \mathrm{~m}^{3} / \mathrm{m}^{2}$ of remains, and $1.1810 \mathrm{~m}^{3} / \mathrm{m}^{2}$ of soil. The soil was the most voluminous waste due to the excavation of the basement, followed by remains and packaging waste.

The CW was quantified in terms of the structure and foundation systems of the analysed building. Other building elements and systems could be assessed once the quantification factors were known and introduced with the same method into the BIM modelling programs. Furthermore, any change in the geometry or in the values of the building elements, as well as their substitution by other elements of different properties, could be automatically reflected in the reports. This automated information related to the types and amounts of waste generated by alternative building elements would enable waste reduction strategies to be evaluated during the design phase (for example, prefabrication, standardisation, and modular coordination).

\subsection{Limitations}

In general, there is a lack of systematisation of the data structure regarding the environmental aspects of the building components. There are no specific attributes to identify the types of waste in the database of the BIM modellers, and hence it is essential to create such identifiers. A homogeneous classification proposal would be interesting. In this respect, the use of the IFC (Industry Foundation Classes) schema [56] could provide an appropriate solution to establish common criteria and nomenclatures among the applications. The IFC is an open international standard (ISO 16739-1:2018) that provides a digital description of the built asset industry and promotes vendor-neutral and usable capabilities across a wide range of hardware devices, software platforms, and interfaces for many different applications. Interoperability is an essential requirement for the exchange of data in BIM methodology. It is the ability of a software product to exchange data with heterogeneous software products in order to streamline and/or automate workflows.

On the other hand, building elements should include information of a more complex nature regarding their properties. In this respect, manufacturers have much to contribute by providing libraries of BIM objects enriched with environmental information, such as the CDW generated during the life cycle of their products. Finally, the integration of the CDW quantification model (15) was verified in a case study (a structural system in a residential building). In order to widen the possibilities of its implementation, more case studies will be necessary both in other building systems (façades, roofs, facilities, etc.) and in other building typologies (offices, hospitals, educational buildings, etc.).

\section{Conclusions}

This study reveals that the reference model of quantification of CDW, which employs building elements in its prediction in the design phase and considers the EWL, can be implemented in the different BIM design programs. The method allows designers to visualise and explore possible corrective measures in order to increase construction efficiency. Moreover, it can enable contractors to identify critical processes in waste generation and to plan control strategies.

The virtualisation of the design process using BIM elements enriched with attributes constitutes a real response to the growing need to include environmental considerations in projects. The proposed method and the information flows generated, through the integrated 
database, enable the identification and quantification of the $\mathrm{CW}$ produced by the building systems defined in the initial design scenarios. The implementation of the CDW quantification model in BIM could therefore help designers in making decisions of a more sustainable nature during the building design phase, thereby contributing towards the improvement of the management of $\mathrm{CDW}$, since it would provide the identification of the typologies and quantities of $\mathrm{CDW}$, which in turn would indicate the waste treatment required.

This investigation constitutes a basis for future research in which the aim is to automate the process of generating the database of the quantification model and the visualisation of both numerical and graphic results with the help of the parametric design tools included in BIM design programs.

Author Contributions: R.Q. has taken part in the conceptualisation, methodology, investigation, writing (original draft preparation), and visualisation; C.L. has taken part in conceptualisation, methodology, investigation, resources, data curation, writing (original draft preparation), writing (review and editing), supervision, and funding acquisition; M.V.M. has taken part in conceptualisation, investigation, and writing (original draft preparation); I.C. has taken part in investigation and methodology. All authors have read and agreed to the published version of the manuscript.

Funding: This research was funded by the Andalusian Government [57] and the Spanish Government, Ministry of Economy, research projects I+D, 2017 (Ref. BIA2017-84830-R) [58].

Institutional Review Board Statement: Not applicable.

Informed Consent Statement: Not applicable.

Data Availability Statement: Data are available in a publicly accessible repository.

Acknowledgments: The authors are grateful to the Consejería de Vivienda y Ordenación del Territorio de la Junta de Andalucía for subsidising the research project "Construction Waste Reduction in the Design and Construction of Dwellings in Andalusia" [57] and to the Spanish Ministry of Economy for supporting the research project entitled "Development of a unified tool for the quantification and reduction of environmental, social, and economic impact of life cycle of the buildings on Building Information Modelling (BIM) platforms" (ref. BIA2017-84830-R) [58], in which this study has been developed. The authors also wish to thank the Municipal Public Housing Company in Seville (EMVISESA) [54] for providing the case study, and the companies and stakeholders involved for their help and support.

Conflicts of Interest: The authors declare there to be no conflict of interest.

\section{References}

1. European Commission (EU). Internal Market, Industry, Entrepreneurship and SMEs. Sectors. Construction. 2020. Available online: https:/ / ec.europa.eu/growth/sectors/construction_en (accessed on 22 June 2021).

2. European Commission (EU). Construction and Demolition Waste (CDW). 2020. Available online: https://ec.europa.eu/ environment/waste/construction_demolition.htm (accessed on 22 June 2021).

3. United Nation. Sustainable Development Goals. 2015. Available online: https://www.un.org/sustainabledevelopment/ sustainable-development-goals/ (accessed on 22 June 2021).

4. European Commission (EU). Circular Economy_Principles for Building Design. 2020. Available online: https://ec.europa.eu/ docsroom/documents/39984 (accessed on 22 June 2021).

5. Adams, K.T.; Osmani, M.; Thorpe, T.; Thornback, J. Circular economy in construction: Current awareness, challenges and enablers. Proc. Inst. Civ. Eng. Waste Resour. Manag. 2017, 170, 15-24. [CrossRef]

6. Veleva, V.; Bodkin, G.; Todorova, S. The need for better measurement and employee engagement to advance a circular economy: Lessons from Biogen's “zero waste" journey. J. Clean. Prod. 2017, 154, 517-529. [CrossRef]

7. Gómez-Soberón, J.M.; Saldaña-Márquez, H.; Gámez-García, D.C.; Gómez-Soberón, M.C.; Arredondo-Rea, S.P.; Corral-Higuera, R. A comparative study of indoor pavements waste generation during construction through simulation tool. Int. J. Sustain. Energ. Dev. 2016, 5, 243-251. [CrossRef]

8. Salgin, B.; Arroyo, P.; Ballard, G. Exploring the relationship between lean design methods and C\&D waste reduction: Three case studies of hospital projects in California. Rev. Ing. Constr. 2016, 31, 191-200. [CrossRef]

9. Ajayi, S.O.; Oyedele, L.O.; Akinade, O.O.; Bilal, M.; Alaka, H.A.; Owolabi, H.A. Optimising material procurement for construction waste minimization: An exploration of success factors. Sustain. Mater. Technol. 2017, 11, 38-46. [CrossRef]

10. Esa, M.R.; Halog, A.; Rigamonti, L. Strategies for minimizing construction and demolition wastes in Malaysia. Resour. Conserv. Recycl. 2017, 120, 219-229. [CrossRef] 
11. Mah, C.M.; Fujiwara, T.; Ho, C.S. Life cycle assessment and life cycle costing toward eco-efficiency concrete waste management in Malaysia. J. Clean. Prod. 2018, 172, 3415-3427. [CrossRef]

12. Vázquez-López, E.; Garzia, F.; Pernetti, R.; Solís-Guzmán, J.; Marrero, M. Assessment model of end-of-life costs and waste quantification in selective demolitions: Case studies of nearly zero-energy buildings. Sustainability 2020, 12, 6255. [CrossRef]

13. de Magalhães, R.F.; Danilevicz, Â.M.F.; Saurin, T.A. Reducing construction waste: A study of urban infrastructure projects. Waste Manag. 2017, 67, 265-277. [CrossRef]

14. Solís-Guzmán, J.; Marrero, M.; Montes, M.V.; Ramírez-de-Arellano, A. A Spanish model for quantification and management of construction waste. Waste Manag. 2009, 29, 2542-2548. [CrossRef]

15. Llatas, C. A model for quantifying construction waste in projects according to the European waste list. Waste Manag. 2011, 31, 1261-1276. [CrossRef] [PubMed]

16. Llatas, C.; Osmani, M. Development and validation of a building design waste reduction model. Waste Manag. 2016, 56, 318-336. [CrossRef]

17. Akanbi, L.A.; Oyedele, A.O.; Oyedele, L.O.; Salami, R.O. Deep learning model for demolition waste prediction in a circular economy. J. Clean. Prod. 2020, 274, 122843. [CrossRef]

18. Llatas, C.; Bizcocho, N.; Soust-Verdaguer, B.; Montes, M.V.; Quiñones, R. An LCA-based model for assessing prevention versus non-prevention of construction waste in buildings. Waste Manag. 2021, 126, 608-622. [CrossRef]

19. Quiñones, R.; Llatas, C.; Montes, M.V.; Cortés, I. Rehabilitation vs. demolition methodology to compare the waste generated in alternative scenarios of building elements in BIM during the design stage. In Critical Thinking in the Sustainable Rehabilitation and Risk Management of the Built Environment. CRIT-RE-BUILT 2019; Springer Series in Geomechanics and Geoengineering; Rotaru, A., Ed.; Springer: Cham, Switzerland, 2021; pp. 506-518. [CrossRef]

20. Won, J.; Cheng, J.C.P. Identifying potential opportunities of building information modeling for construction and demolition waste management and minimization. Automat. Constr. 2017, 79, 3-18. [CrossRef]

21. van Nederveen, G.A.; Tolman, F.P. Modelling multiple views on buildings. Automat. Constr. 1992, 1, 215-224. [CrossRef]

22. Cao, D.; Li, H.; Wang, G. Impacts of building information modeling (BIM) implementation on design and construction performance: A resource dependence theory perspective. Front. Eng. Manag. 2017, 4, 20-34. [CrossRef]

23. Santos, R.; Costa, A.A.; Grilo, A. Bibliometric analysis and review of Building Information Modeling literature published between 2005 and 2015. Automat. Constr. 2017, 80, 118-136. [CrossRef]

24. Yalcinkaya, M.; Singh, V. Patterns and trends in Building Information Modeling (BIM) research: A Latent Semantic Analysis. Automat. Constr. 2015, 59, 68-80. [CrossRef]

25. Zhao, X. A scientometric review of global BIM research: Analysis and visualization. Automat. Constr. 2017, 80, 37-47. [CrossRef]

26. Nguyen, T.H.; Shehab, T.; Gao, Z. Evaluating sustainability of architectural designs using Building Information Modeling. Open Constr. Build. Technol. J. 2010, 4, 1-8. [CrossRef]

27. Ahmad, T.; Aibinu, A.; Thaheem, M.J. BIM-based iterative tool for sustainable building design: A conceptual framework. Proced. Eng. 2017, 180, 782-792. [CrossRef]

28. Oduyemi, O.; Okoroh, M.I.; Fajana, O.S. The application and barriers of BIM in sustainable building design. J. Facil. Manag. 2017, 15, 15-34. [CrossRef]

29. Xu, X.; Mumford, T.; Zou, P.X.W. Life-cycle Building Information Modelling (BIM) engaged framework for improving building energy performance. Energy Build. 2020, 110496. [CrossRef]

30. Liu, Z.; Osmani, M.; Demian, P.; Baldwin, A. A BIM-aided construction waste minimization framework. Automat. Constr. 2015, 59, 1-23. [CrossRef]

31. Won, J.; Cheng, J.C.P.; Lee, G. Quantification of construction waste prevented by BIM-based design validation: Case studies in South Korea. Waste Manag. 2016, 49, 170-180. [CrossRef] [PubMed]

32. Bilal, M.; Oyedele, L.O.; Munir, K.; Ajayi, S.O.; Akinade, O.O.; Owolabi, H.A.; Alaka, H.A. The application of web of data technologies in building materials information modelling for construction waste analytics. Sustain. Mater. Technol. 2017, 11, 28-37. [CrossRef]

33. Porwal, A.; Hewage, K. Building Information Modeling-based analysis to minimize waste rate of structural reinforcement. J. Constr. Eng. Manag. 2012, 138, 943-954. [CrossRef]

34. Guerra, B.C.; Bakchan, A.; Leite, F.; Faust, K.M. BIM-based automated construction waste estimation algorithms: The case of concrete and drywall waste streams. Waste Manag. 2019, 87, 825-832. [CrossRef]

35. Cheng, J.C.P.; Ma, L.Y.H. A BIM-based system for demolition and renovation waste estimation and planning. Waste Manag. 2013, 33, 1539-1551. [CrossRef] [PubMed]

36. Akinade, O.O.; Oyedele, L.O.; Omoteso, K.; Ajayi, S.O.; Bilal, M.; Owolabi, H.A.; Alaka, H.A.; Ayris, L.; Looney, J.H. BIM-based deconstruction tool: Towards essential functionalities. Int. J. Sustain. Built Environ. 2017, 6, 260-271. [CrossRef]

37. Akanbi, L.A.; Oyedele, L.O.; Akinade, O.O.; Ajayi, A.O.; Davila Delgado, M.; Bilal, M.; Bello, S.A. Salvaging building materials in a circular economy: A BIM-based whole-life performance estimator. Resour. Conserv. Recycl. 2018, 129, 175-186. [CrossRef]

38. Zhang, K.; Jia, J. Promotion of the Application of BIM in China-A BIM-Based Model for Construction Material Recycling. Recycling 2021, 6, 16. [CrossRef] 
39. Akinade, O.O. BIM-Based Software for Construction Waste Analytics Using Artificial Intelligence Hybrid Models. Ph.D. Thesis, Philosophy University of the West of England, Bristol, UK, 2017. Available online: https:// eprints.uwe.ac.uk/31762 (accessed on 22 June 2021).

40. Mandujano, M.G.; Alarcón, L.F.; Kunz, J.; Mourgues, C. Identifying waste in virtual design and construction practice from a lean thinking perspective: A meta-analysis of the literature. Rev. Constr. 2016, 15, 107-118. [CrossRef]

41. Lu, W.; Webster, C.; Chen, K.; Zhang, X.; Chen, X. Computational Building Information Modeling for construction waste management: Moving from rhetoric to reality. Renew. Sustain. Energy Rev. 2017, 68, 587-595. [CrossRef]

42. Bilal, M.; Oyedele, L.O.; Qadir, J.; Munir, K.; Akinade, O.O.; Ajayi, S.O.; Alaka, H.A.; Owolabi, H.A. Analysis of critical features and evaluation of BIM software: Towards a plug-in for construction waste minimization using big data. Int. J. Sustain. Build. Technol. Urban. Dev. 2016, 6, 211-228. [CrossRef]

43. Kalinichuk, S. Building Information Modeling comprehensive overview. J. Syst. Integr. 2015, 3, 25-34. [CrossRef]

44. Akinade, O.O.; Oyedele, L.O.; Ajayi, S.O.; Bilal, M.; Alaka, H.A.; Owolabi, H.A.; Arawomo, O.O. Designing out construction waste using BIM technology: Stakeholders' expectations for industry deployment. J. Clean. Prod. 2018, 180, 375-385. [CrossRef]

45. Li, C.Z.; Zhao, Y.; Xiao, B.; Yu, B.; Tam, V.W.Y.; Chen, Z.; Ya, Y. Research trend of the application of information technologies in construction and demolition waste management. J. Clean. Prod. 2020, 263, 121458. [CrossRef]

46. Gupta, S.; Jha, K.N.; Vyas, G. Proposing Building Information Modeling-based theoretical framework for construction and demolition waste management: Strategies and tools. Int. J. Constr. Manag. 2020. [CrossRef]

47. European Commission. Waste Classification and the European List of Waste. 2020. Available online: https://ec.europa.eu/ environment/waste/framework/list.htm (accessed on 22 June 2021).

48. Ministry of Development, Infrastructure and Territorial Planning of the Andalusian Government. Base de Costes de la Construcción de Andalucía (BCCA)_Andalusian Construction Costs Database. 2017. Available online: https: //www.juntadeandalucia.es/organismos/fomentoinfraestructurasyordenaciondelterritorio/areas/vivienda-rehabilitacion/ planes-instrumentos/paginas/vivienda-bcca.html (accessed on 22 June 2021). (In Spanish)

49. buildingSMART International. Certified Software. 2020. Available online: https://www.buildingsmart.org/compliance/ software-certification/certified-software/ (accessed on 22 June 2021).

50. Nemetschek Allplan Systems. Allplan 2021. Available online: https://www.allplan.com/es/ (accessed on 22 June 2021).

51. Graphisoft Nemetschek Company. Archicad 24. Available online: https://graphisoft.com/es/ (accessed on 22 June 2021).

52. Autodesk. Revit 2021. 2020. Available online: https://www.autodesk.es/products/ (accessed on 22 June 2021).

53. BIM FORUM. Level of Development LOD Specification for Building Information Models and Data. 2021. Available online: https: / / www.bimforum.org/lod (accessed on 22 June 2021).

54. EMVISESA. Empresa Municipal de la Vivienda de Sevilla. 2020. Available online: https://www.emvisesa.org/ (accessed on 22 June 2021). (In Spanish)

55. Spanish Ministry of Development. Statistics on Building Construction. 2020. Available online: https://m.fomento.gob.es/ NR/rdonlyres/C9BE867C-8552-4CA8-BE89-B26F13910CED/145740/ConstruccionEdificios2016.pdf (accessed on 22 June 2021). (In Spanish)

56. buildingSMART International. Industry Foundation Classes (IFC). 2021. Available online: https:/ / www.buildingsmart.org/ standards/bsi-standards/industry-foundation-classes/ (accessed on 22 June 2021).

57. Andalusian Government. Grants for Research on Housing and Architecture. Grant Call. Waste Reduction in the Design and Construction of Dwellings in Andalusia, Spain. 2009. Available online: https:/ /www.juntadeandalucia.es/organismos/ fomentoinfraestructurasyordenaciondelterritorio/areas/vivienda-rehabilitacion/planes-instrumentos/paginas/proyectorcds.html/ (accessed on 22 June 2021). (In Spanish)

58. Spanish Government. Ministry of Economy. Call Research Projects I+D. 2017. Development of a Unified Tool for the Quantification and Reduction of Environmental, Social and Economic Impacts of Life Cycle Buildings in Building Information Modeling (BIM) Platforms. 2018; Ref. BIA2017-84830-R. Available online: https: / investigacion.us.es/sisius/sis_proyecto.php?idproy=28472/ (accessed on 22 June 2021). (In Spanish) 